ISSN 1392-3196 / e-ISSN 2335-8947

Zemdirbyste-Agriculture, vol. 102, No. 2 (2015), p. 159-166

DOI 10.13080/z-a.2015.102.021

\title{
Chlorophyll values as a measure of genetic variation of switchgrass (Panicum virgatum L.) populations under cool temperate climate conditions
}

\author{
Žilvinas LIATUKAS, Nijolè LEMEŽIENĖ, Bronislava BUTKUTĖ, Jurgita CESEVIČIENĖ, \\ Giedrè DABKEVIČIENE் \\ Institute of Agriculture, Lithuanian Research Centre for Agriculture and Forestry \\ Instituto 1, Akademija, Kedainiai distr., Lithuania \\ E-mail: liatukas@1zi.lt
}

\begin{abstract}
The goal of this study was to evaluate the variability of SPAD chlorophyll meter values in switchgrass (Panicum virgatum L.) accessions and improve the selection of plants most suitable for biofuel. Chlorophyll values were recorded five times during plant vegetation from stem elongation to seed filling stages for two consecutive years. Chlorophyll content was increasing from the stem elongation to the anthesis and later declined. Chlorophyll values reached the maximal mean values of 36.8 to 42.3 (device units) during anthesis depending on the evaluation year and the nursery evaluated. This shows that Lithuanian climate conditions are favourable for photosynthetic activity of switchgrass. Chlorophyll values were successfully differentiated at the accession and individual plant level. As a cross-pollinating species, switchgrass plants, characterized by high chlorophyll values, should be selected until anthesis. At this stage the differences between chlorophyll value coefficients of variation of the accessions were similar to those during the anthesis. The mean coefficients of the variation of accessions' chlorophyll values during heading ranged from $4.98 \%$ to $15.0 \%$. Such coefficients show low variability within the accessions but a higher possibility for the selection of plants with desirable chlorophyll values from a broad range of accessions. Selection of plants with similar chlorophyll values should accelerate development of new cultivars.
\end{abstract}

Key words: chlorophyll, growth stages, selection, SPAD readings.

\section{Introduction}

Switchgrass, a perennial C4 type warm-season grass native to the prairies of North America, has been identified by the US Department of Energy as its main species of emphasis for the development into a herbaceous biomass fuel crop (Vogel, Jung, 2000). The species is able to adapt to the growth at different altitudes (Fike et al., 2006). It has become one of the potential new crops in the European countries with Mediterranean climate in the South and oceanic climate of the Western Europe (Monti, 2012). The biomass from switchgrass could be used as a multipurpose bioenergy feedstock for biogas, bioethanol of the second generation and direct combustion (Demirbas, 2003).

Lithuania is European North where switchgrass could be effectively grown (Elbersen, 2001; Wullschleger et al., 2010). Switchgrass investigations under cool temperate climate conditions are scarce. Initial research on switchgrass showed promising results of this grass as solid biofuel and biogas stock under Lithuanian temperate climate conditions (Butkute et al., 2013).

Comprehensive studies have demonstrated the use of a hand held chlorophyll meter SPAD 502 for evaluation of chlorophyll level in plants as in the most cases strong correlations were shown between the results of the mentioned device and the results of traditional methods (Giunta et al., 2002; Udding et al., 2007). The impact of various factors on a chlorophyll level can be evaluated using a SPAD chlorophyll meter (Martinez, Guiamet, 2004; Chunjiang et al., 2007) as well as other devices (Özyiğit, Bilgen, 2011). SPAD chlorophyll meter readings were used for the evaluations of the genetic variation in the populations of many plants as well (Giunta et al., 2002; Hassan et al., 2009; Songsri et al., 2009; Kashiwagi et al., 2010). The research works on switchgrass are very numerous and comprehensive. However, the available information about switchgrass investigations using SPAD chlorophyll meter reading is very limited (Madakadze et al., 1999). This research showed the relationships between SPAD chlorophyll meter readings, a nitrogen level and a grass yield. On the other hand, the photosynthetic peculiarities of switchgrass are investigated at some level (Wullschleger et al., 1996; Mitchell, 2012).

The new cultivar development undergoes several stages. One of them is to meet the European standards of the new cultivar distinctness, uniformity 
and stability (DUS). The new cultivar description and evaluation according to the DUS standards are performed under field conditions mainly using visual evaluations and measurements (UPOV, 2002). Switchgrass is a cross-pollinated plant (Kwrr, Stewart, 2012); therefore, its cultivars consist of genetically and phenotypically different plants. The uniformity of plants must be high enough to fit the standards. The evaluation of the parental material as well as subsequent progenies using SPAD chlorophyll meter readings should enable selecting of the more uniform populations as well as plants in these populations. A survey of SPAD chlorophyll meter reading variations of the switchgrass accessions among populations, plants and years should provide a clearer differentiation of these accessions and a possibility for the selection of desirable switchgrass plants.

The task of this study was to evaluate the variability of SPAD (Soil and Plant Analyzer Development) chlorophyll meter values in switchgrass accessions to improve the selection of plants most suitable for biofuel. A plant with similar chlorophyll values should be more desirable for developing of a new cultivar in shorter terms.

\section{Material and methods}

The experimental collection was set up using the seedlings grown in a greenhouse. The seeds for the germplasm collections of switchgrass were obtained from the Plant Genetic Resources Conservation Unit (PGRCU) of the United States Department of Agriculture and Agricultural Research Service. The part of the collection set up in 2010 was qualified as a germplasm collection of the second and third harvest year (nursery A) and the part set up in 2011 - as a germplasm collection of the first and second harvest year (nursery B), respectively in 2012 and 2013. The tested accessions included 8 varieties and 32 wild ecotypes. Each accession consisted of 32 plants spaced $0.5 \mathrm{~m}$ apart. Twenty accessions were set up in 2010 and 20 accessions were set up in 2011, in cereal grass breeding nurseries of Institute of Agriculture, Lithuanian Research Centre for Agriculture and Forestry.

The soil of the experimental site is EndocalcariEpihypogleyic Cambisol (CMg-p-w-can) with the following characteristics of a plough layer $(0-25 \mathrm{~cm})$ : $\mathrm{pH}$ ranging from 7.1 to 7.3 , humus content - from 2.2 to $3.0 \%$, available phosphorus $\left(\mathrm{P}_{2} \mathrm{O}_{5}\right)-$ from 160 to $200 \mathrm{mg}$ $\mathrm{kg}^{-1}$, available potassium $\left(\mathrm{K}_{2} \mathrm{O}\right)-120$ and $150 \mathrm{mg} \mathrm{kg}$ in fields where nurseries were established in 2010 and 2011. Fertilizer $\mathrm{N}_{60} \mathrm{P}_{60} \mathrm{~K}_{60}$ was applied pre-planting once and $\mathrm{N}_{60}$ was applied each spring of the following years. Weeds were controlled by herbicides every year.

The chlorophyll meter SPAD-502 (Konica Minolta, Japan) measurements in the switchgrass collection were carried out five times in 2012 and 2013 during vegetation periods at the stages of stem elongation (1), booting (2), heading (3), anthesis (4) and seed filling (5). All survived plants per population were evaluated. The uppermost fully expanded leaf blades were measured. Three leaves were selected per plant; each leaf was measured in 9 places covering all leaf blade parts. The chlorophyll values of the ten individual plants were selected to be presented in Figure 1. Data of all survived plants were presented in Figure 2. Nursery A had 142 and 183, and nursery B - 60 and 110 plants in 2012 and 2013, respectively.

The weather conditions were rather different between the seasons. The first season 2011-2012 was characterized by a mild winter, early spring and wet summer. The second season 2012-2013 was characterized by a cold and long lasting winter, a very late dry and warm spring and a changeable summer with heat waves.

The data were processed by statistical analysis ANOVA.

\section{Results}

Regardless of the differences in the meteorological conditions during the growing season, switchgrass started vegetation very similarly with a few days' difference in the second half of May during both years and in both nurseries. The majority accessions of nursery A overwintered well during both years, whereas the accessions of nursery B were highly damaged by winter in 2012 but not in 2013.

The dynamics of SPAD values of ten individual plants of switchgrass over the two years are presented in Figure 1. In most cases, chlorophyll concentration was increasing until anthesis. The evaluation during seed filling stage showed a decrease in most cases. The accessions of nursery A showed more stable chlorophyll values among the genotypes in both years compared to the accessions of nursery B. The chlorophyll values were higher during the first evaluation of both groups in 2013. The main reason could be much later but warmer and dryer spring and the first half of June in 2013 compared to 2012. The peak of chlorophyll values was reached during anthesis. Chlorophyll values ranged from 32 to 48 and from 32 to 43 in the accessions of nursery A, respectively in 2012 and 2013. Only the accession PI 642308 of nursery A showed a slightly lower chlorophyll value during anthesis (43) compared to the heading stage (44) in 2013. Chlorophyll values ranged from 37 to 50 and from 33 to 45 in the accessions of nursery B, respectively in 2012 and 2013. Only accession PI 477003 of nursery B showed a slightly lower chlorophyll value during anthesis (44) compared to the seed filling stage (45) in 2012. The accessions with higher chlorophyll values during anthesis showed higher chlorophyll values during the seed filling stage. As well as higher chlorophyll values of the accessions during the stem elongation showed the tendency to retain higher chlorophyll values during subsequent evaluations.

Plant numbers for chlorophyll evaluations in nurseries A and B during 2012 and 2013 differed due to overwintering as well as different cutting regimes. Nursery A had 142 and 183 and nursery B - 60 and 110 plants in 2012 and 2013, respectively. The mean 

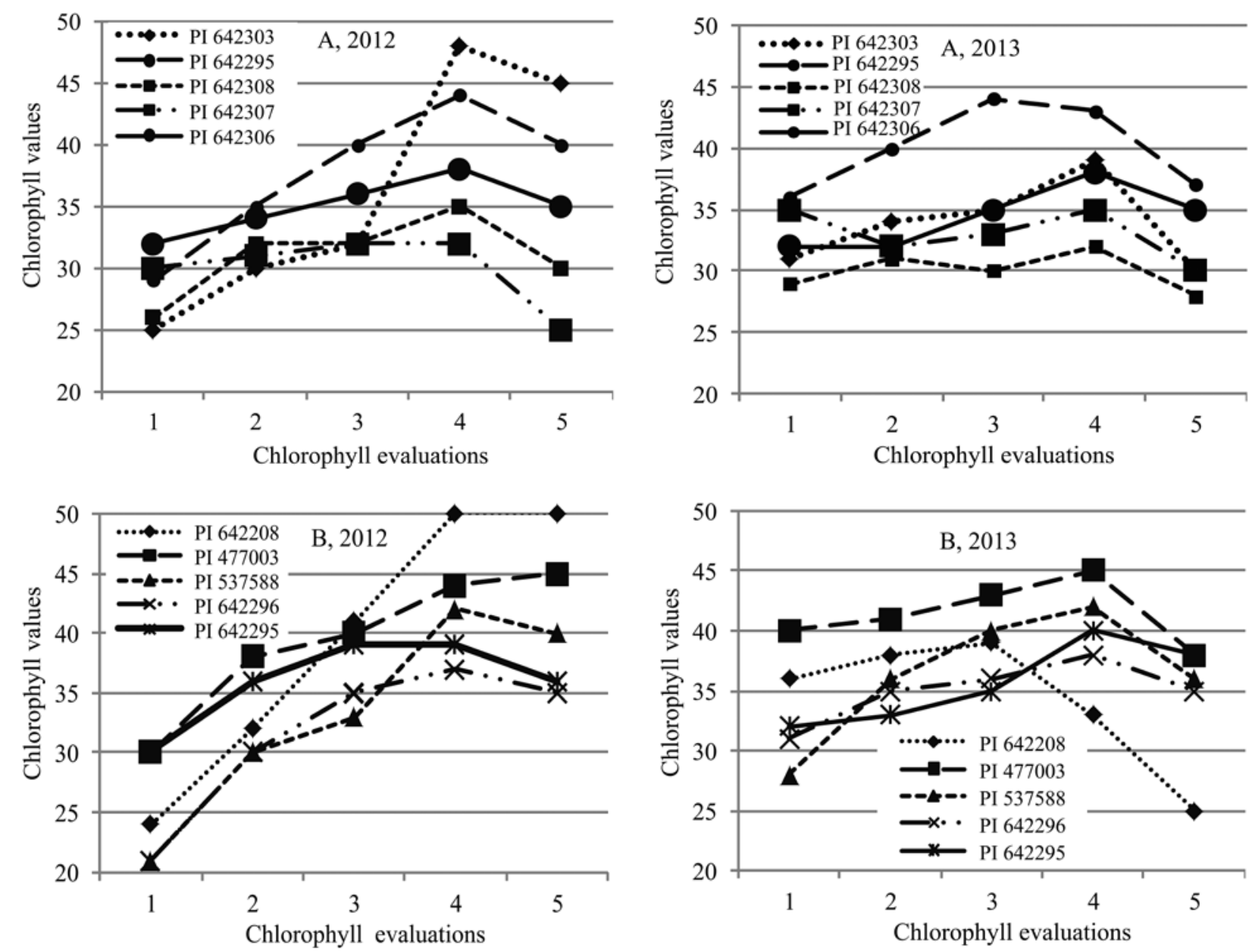

Stages: 1 - stem elongation, 2 - booting, 3 - heading, 4 - anthesis, 5 - seed filling

Figure 1. Dynamic of SPAD chlorophyll meter values of the ten individual plants from stem elongation to seed filling stages of nurseries A and B, 2012 and 2013

chlorophyll values of plants in nursery A during five evaluations were 28.1, 32.4, 34.5, 36.8 and 31.8 in 2012 (Fig. 2). The minimal and maximal values differed from 1.5 to 3.2 fold during the booting and seed filling stages, respectively. The mean chlorophyll values were slightly higher in 2013. These values were 34.0, 34.9, 35.9, 36.9 and 32.0 , respectively. However, the minimal and maximal values differed only from 1.75 to 2.2 fold, during the stem elongation and booting stages, respectively.

Winter damaged nursery B had a lower plant number per plot area compared to nursery A. Therefore, the plants of nursery $\mathrm{A}$ received more nitrogen per plant. The mean chlorophyll values were slightly lower during the first evaluation at stem elongation stage (26.8) compared to nursery A (28.1) in 2012. However, the mean chlorophyll values increased higher during next evaluations and they did not decrease during the seed filling stage (34.5, 39.9, 42.3 and 42.0, respectively). The minimal and maximal chlorophyll values differed only from 1.35 to 1.7 fold, during the anthesis and stem elongation stages, respectively. This difference was much lower in 2013; it differed from 1.7 to 1.9 fold, during the stem elongation to anthesis and seed filling stages, respectively. The changes of the mean chlorophyll values during the evaluations showed higher values but a very similar tendency to the results of nursery A. These values were $37.3,38.8,40.8,42.3$ and 38.3 , respectively.

The variations of chlorophyll values presented in Tables 1 and 2 respond to two contradictive traits the variability and similarity of screened switchgrass populations by chlorophyll content. The differences in the coefficients of variation among the selected populations during all growth stages in both nurseries showed a considerable variability by chlorophyll values and at the same moment by chlorophyll content. The populations of nursery A were characterized by the decrease of coefficient of variation (CV) variability from the stem elongation to anthesis stages and increased the variability at the seed filling stage in both years. CV decreased from $3.94 \%$ to $21.2 \%$ (5.43 fold) and from $7.77 \%$ to $13.6 \%$ ( 1.75 fold), and increased from $9.21 \%$ to $34.9 \%$ (3.79 fold) in 2012. A lower variation of CV was obtained in 2013 when it decreased from $4.52 \%$ to $14.2 \%$ (3.14 fold) to $6.81 \%$ to $13.1 \%$ (1.92 fold) and increased from $6.26 \%$ to $19.8 \%$ (3.16 fold) during the stem elongation to seed filling stage, respectively. The minimal and maximal 

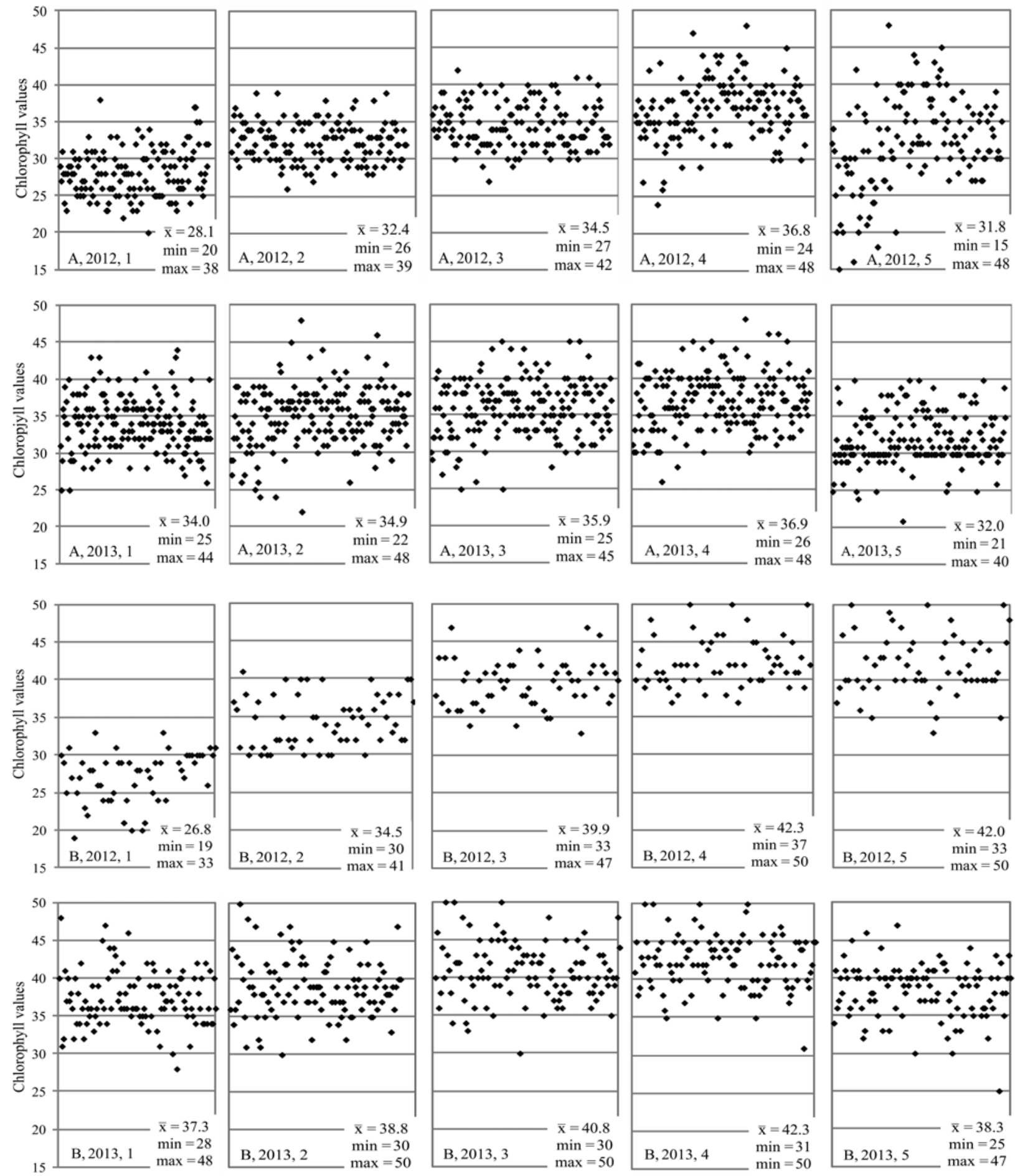

Stages: 1 - stem elongation, 2 - booting, 3 - heading, 4 - anthesis, 5 - seed filling

Figure 2. SPAD chlorophyll meter values of individual plants from stem elongation to seed filling stages in nurseries $A$ and B, 2012 and 2013

chlorophyll values showed a stable increase from the stem elongation to anthesis stages and a stable decrease during the seed filling stage in both years.

The populations of nursery B were characterized by a decrease of $\mathrm{CV}$ variability from the stem elongation to booting stages and again an increased variability from the heading to seed filling stages in both years. The variability of $\mathrm{CV}$ decreased from $5.71 \%$ to $16.5 \%(2.89$ fold) and from $7.09 \%$ to $12.9 \%$ (1.82 fold), and again increased from $5.02 \%$ to $11.6 \%$ (2.31 fold) and from $5.49 \%$ to $16.9 \%$ (3.08 fold) in 2012 . The same tendency and variation of $\mathrm{CV}$ were obtained in 2013 when it decreased from $6.59 \%$ to $15.5 \%$ (2.35 fold) and from $6.08 \%$ to $11.2 \%$ (1.84 fold), and increased from $4.98 \%$ to $10.9 \%$ (2.21 fold) and from $6.91 \%$ to $18.3 \%$ (2.65 fold) from the stem elongation to seed filling stages, respectively. 
Table 1. SPAD chlorophyll meter mean values and coefficient of variation (CV) of switchgrass selected populations from stem elongation to seed filling stages in nursery A, 2012-2013

\begin{tabular}{|c|c|c|c|c|c|c|c|c|c|c|}
\hline \multirow{3}{*}{$\begin{array}{c}\text { Catalogue No. } \\
\text { of PGRCU }\end{array}$} & \multicolumn{10}{|c|}{ Chlorophyll evaluations, 2012} \\
\hline & \multicolumn{2}{|c|}{$1^{\text {st }}$} & \multicolumn{2}{|c|}{$2^{\text {nd }}$} & \multicolumn{2}{|c|}{$3^{\text {rd }}$} & \multicolumn{2}{|c|}{$4^{\text {th }}$} & \multicolumn{2}{|c|}{$5^{\text {th }}$} \\
\hline & SPAD & $\mathrm{CV} \%$ & SPAD & $\mathrm{CV} \%$ & SPAD & $\mathrm{CV} \%$ & SPAD & $\mathrm{CV} \%$ & SPAD & $\mathrm{CV} \%$ \\
\hline PI 642295 & 26.7 & 6.98 & 32.3 & 7.38 & 35.5 & 8.20 & 37.8 & 8.84 & 36.0 & 9.21 \\
\hline PI 642296 & 28.2 & 10.5 & 30.9 & 7.85 & 33.4 & 6.94 & 37.5 & 7.77 & 33.5 & 15.8 \\
\hline PI 642297 & 27.3 & 14.5 & 33.4 & 6.56 & 36.1 & 5.54 & 39.4 & 9.90 & 33.4 & 34.9 \\
\hline PI 642298 & 29.7 & 13.3 & 33.6 & 10.0 & 35.1 & 10.6 & 39.9 & 8.55 & 32.7 & 16.3 \\
\hline PI 642302 & 27.6 & 21.2 & 30.8 & 8.77 & 33.8 & 10.7 & 39.2 & 8.83 & 37.3 & 17.6 \\
\hline PI 642305 & 25.6 & 11.0 & 31.3 & 8.58 & 33.5 & 9.56 & 38.3 & 11.6 & 32.7 & 21.8 \\
\hline PI 642306 & 27.1 & 12.7 & 31.8 & 4.98 & 33.3 & 8.19 & 34.3 & 13.6 & 25.0 & 30.4 \\
\hline PI 642308 & 26.6 & 8.74 & 31.4 & 8.62 & 33.0 & 7.42 & 35.9 & 11.6 & 33.1 & 13.3 \\
\hline PI 642194 & 30.9 & 3.94 & 34.1 & 6.47 & 35.8 & 7.88 & 36.6 & 9.18 & 33.1 & 17.4 \\
\hline PI 642195 & 31.9 & 9.10 & 33.5 & 8.19 & 34.7 & 7.51 & 33.5 & 12.2 & 28.4 & 24.0 \\
\hline \multirow[t]{2}{*}{ Mean } & 28.2 & 11.2 & 32.3 & 7.74 & 34.4 & 8.30 & 37.2 & 10.2 & 32.5 & 20.1 \\
\hline & \multicolumn{10}{|c|}{ Chlorophyll evaluations, 2013} \\
\hline PI 642295 & 32.9 & 4.52 & 33 & 18.5 & 33.6 & 15.0 & 35.3 & 10.9 & 26.8 & 8.47 \\
\hline PI 642296 & 34.1 & 9.84 & 32.4 & 14.0 & 33.8 & 14.0 & 35.0 & 12.6 & 28.7 & 9.35 \\
\hline PI 642297 & 33 & 14.2 & 32.7 & 15.2 & 34.1 & 14.1 & 34.2 & 13.1 & 26.7 & 11.7 \\
\hline PI 642298 & 34 & 7.86 & 34.9 & 8.86 & 35.7 & 9.93 & 36.9 & 9.32 & 30.0 & 10.9 \\
\hline PI 642302 & 30.6 & 6.22 & 33.7 & 8.94 & 34.9 & 8.83 & 35.6 & 7.59 & 26.4 & 19.8 \\
\hline PI 642305 & 31.6 & 8.72 & 34.8 & 8.22 & 35.0 & 8.92 & 35.3 & 8.25 & 25.9 & 11.5 \\
\hline PI 642306 & 32.9 & 6.16 & 35.0 & 12.6 & 36.1 & 10.6 & 36.8 & 8.89 & 27.8 & 11.0 \\
\hline PI 642308 & 31.9 & 9.96 & 34.9 & 6.95 & 34.9 & 7.11 & 36.9 & 6.81 & 27.5 & 9.12 \\
\hline PI 642194 & 37.6 & 7.47 & 36.9 & 8.42 & 38.2 & 8.53 & 38.4 & 10.7 & 31.8 & 6.26 \\
\hline PI 642195 & 35.2 & 10.9 & 37.3 & 11.8 & 36.6 & 10.6 & 36.4 & 10.5 & 32.6 & 8.84 \\
\hline Mean & 33.4 & 8.41 & 34.6 & 11.3 & 35.3 & 10.8 & 36.1 & 9.9 & 28.4 & 10.7 \\
\hline
\end{tabular}

PGRCU - Plant Genetic Resources Conservation Unit

Table 2. SPAD chlorophyll meter mean values and coefficient of variation (CV) of switchgrass selected populations from stem elongation to seed filling stages in nursery B, 2012-2013

\begin{tabular}{|c|c|c|c|c|c|c|c|c|c|c|}
\hline \multirow{3}{*}{$\begin{array}{c}\text { Catalogue No. } \\
\text { of PGRCU }\end{array}$} & \multicolumn{10}{|c|}{ Chlorophyll evaluations, 2012} \\
\hline & \multicolumn{2}{|c|}{$1^{\mathrm{st}}$} & \multicolumn{2}{|c|}{$2^{\text {nd }}$} & \multicolumn{2}{|c|}{$3^{\text {rd }}$} & \multicolumn{2}{|c|}{$4^{\text {th }}$} & \multicolumn{2}{|c|}{$5^{\text {th }}$} \\
\hline & SPAD & $\mathrm{CV} \%$ & SPAD & $\mathrm{CV} \%$ & SPAD & $\mathrm{CV} \%$ & SPAD & $\mathrm{CV} \%$ & SPAD & $\mathrm{CV} \%$ \\
\hline PI 642208 & 27.0 & 10.9 & 36.0 & 12.0 & 39.5 & 10.6 & 44.3 & 11.1 & 44.3 & 12.4 \\
\hline PI 537588 & 25.9 & 16.5 & 34.5 & 11.1 & 39.6 & 11.6 & 40.7 & 3.70 & 40.6 & 5.49 \\
\hline PI 642284 & 22.8 & 11.6 & 35.8 & 9.24 & 40.0 & 7.07 & 43.8 & 9.76 & 44.5 & 16.9 \\
\hline PI 642295 & 25.7 & 12.7 & 35.2 & 10.6 & 41.0 & 9.38 & 42.6 & 5.89 & 41.1 & 10.4 \\
\hline PI 642191 & 22.8 & 15.3 & 32.6 & 12.9 & 38.2 & 7.50 & 43.5 & 11.1 & 44.5 & 12.7 \\
\hline PI 642296 & 27.4 & 8.95 & 33.8 & 10.1 & 39.1 & 6.94 & 41.6 & 4.98 & 42.2 & 8.01 \\
\hline PI 642203 & 25.0 & 16.3 & 34.8 & 10.9 & 39.3 & 5.29 & 41.0 & 8.79 & 42.7 & 8.87 \\
\hline PI 476291 & 27.4 & 8.89 & 35.1 & 11.9 & 41.6 & 8.99 & 44.3 & 7.42 & 44.8 & 9.31 \\
\hline PI 477003 & 30.0 & 12.3 & 35.3 & 7.09 & 41.2 & 5.02 & 42.3 & 4.88 & 43.8 & 7.47 \\
\hline PI 642296 & 30.2 & 5.71 & 35.8 & 7.57 & 39.7 & 5.67 & 42.2 & 4.08 & 39.5 & 7.29 \\
\hline \multirow[t]{2}{*}{ Mean } & 26.4 & 11.9 & 34.9 & 10.3 & 39.9 & 7.57 & 42.6 & 7.07 & 42.8 & 9.78 \\
\hline & \multicolumn{10}{|c|}{ Chlorophyll evaluations, 2013} \\
\hline PI 642208 & 40.9 & 7.89 & 39.6 & 6.59 & 41.6 & 4.98 & 41.4 & 14.8 & 35.6 & 18.3 \\
\hline PI 537588 & 37.9 & 15.5 & 40.4 & 9.28 & 43.9 & 7.47 & 45.2 & 5.60 & 40.5 & 6.91 \\
\hline PI 642284 & 37.8 & 6.59 & 38.8 & 9.28 & 42.1 & 7.83 & 43.0 & 7.17 & 39.2 & 7.19 \\
\hline PI 642295 & 38.1 & 10.9 & 39.5 & 11.2 & 41.4 & 10.9 & 43.9 & 10.3 & 39.1 & 9.22 \\
\hline PI 642191 & 37.1 & 9.10 & 39.1 & 10.4 & 40.9 & 8.59 & 42.0 & 6.85 & 38.6 & 8.47 \\
\hline PI 642296 & 38.0 & 8.99 & 38.2 & 8.51 & 40.0 & 8.14 & 41.1 & 5.81 & 38.1 & 9.69 \\
\hline PI 642203 & 35.8 & 8.29 & 37.9 & 11.2 & 40.1 & 7.93 & 41.9 & 7.16 & 38.0 & 9.89 \\
\hline PI 476291 & 38.6 & 7.31 & 39.8 & 7.81 & 41.4 & 5.91 & 43.3 & 5.76 & 39.0 & 7.25 \\
\hline PI 477003 & 39.3 & 8.62 & 41.9 & 6.08 & 43.6 & 5.33 & 43.8 & 5.83 & 40.0 & 8.24 \\
\hline PI 642296 & 35.3 & 7.27 & 36.1 & 8.54 & 38.3 & 6.30 & 41.3 & 5.64 & 38.0 & 8.65 \\
\hline Mean & 37.9 & 9.05 & 391 & 8.89 & 41.3 & 7.34 & 42.7 & 7.49 & 38.6 & 9.38 \\
\hline
\end{tabular}

PGRCU - Plant Genetic Resources Conservation Unit 


\section{Discussion}

Switchgrass has a disadvantage in yielding capability during the first harvest years due to the allocation of a large amount of energy for developing a strong root system (McLaughlin, Kszos, 2005). A similar tendency was obtained in Northwest and Southern Europe (Elbersen, 2001; Butkute et al., 2013). However, this trend had no relations with chlorophyll content dynamics presented in this paper. The chlorophyll content variation depended more on the weather conditions and genotypes but not on the year of the nursery establishment. An outbreak of leaf diseases and pests was not noted. Therefore, the weather conditions had the highest impact. Lower chlorophyll values in 2012 compared to 2013 depended on the switchgrass physiological traits that conditioned lower photosynthetic efficiency and/or chlorophyll synthesis under colder conditions compared to warmer ones (Mitchell, 2012). A photosynthetic potential was closely related to the chlorophyll content, therefore, chlorophyll values during the first three evaluations were lower in 2012 compared to chlorophyll values in 2013. The slight variation among the chlorophyll values of the selected individual plants between years might have occurred due to the environmental parameters influencing an individual reaction of each plant. In general, the switchgrass chlorophyll content was rather stable among years and nurseries, whereas the weather conditions were considerably different. This plant species is characterized by a very well developed root system which should eliminate a water deficiency stress under droughty weather conditions (Barney et al., 2009). Such morphological trait more or less eliminates a considerable impact of water compared to the temperature effect on switchgrass as C4 plant.

Chlorophyll minimal and mean values and its dynamics in our trial were similar to the results of Madakadze et al. (1999) experiment but the maximal values were higher in our trial (48-50 compared to 40 42 , depending on the population). The maximal values were recorded at the anthesis stage and the record of chlorophyll values at the seed filling stage showed a rapid decline. The similar trend of chlorophyll dynamics was recorded in various plants (Ramesh et al., 2002; Costa et al., 2003; Kashiwagi et al., 2010).

The marked differences between the minimal and maximal chlorophyll values of individual plants in both years and nurseries showed a considerable possibility for the selection of individual plants possessing high chlorophyll concentration in combinations with other desirable traits. The maximal chlorophyll values were observed during anthesis. However, the individual plant selection by this trait should be done at heading stage to avoid the cross pollination among the plants possessing desirable traits and discarded plants. The results of Babar et al. (2006) and Arunyanark et al. (2009) showing higher correlations of chlorophyll values with biomass at later development stages also support plant selection until anthesis.
A population's coefficient of the variation showed high enough but not so considerable variation as in the case of individual plants. The chlorophyll content is essential for plant competitiveness; therefore, a variation cannot be extremely high at non-adverse conditions of our experiment. Some very high variations could be found when plants are evaluated under extreme conditions (Arunyanark et al., 2009; Hassan et al., 2009; Kashiwagi et al., 2010). A short term breeding strategy should employ the selection of populations characterized by low variability but possessing high mean chlorophyll values. This should allow the selection of plants similar by high chlorophyll values. This way requires growing of the populations consisting of a considerable number of plants as the other traits should be considered according to UPOV (2002). This should allow developing of the new cultivar in shorter terms but possibly possessing lower genetic variability. The selection of plants from a population with high variability should allow developing of a cultivar possessing higher genetic diversity but during longer terms.

\section{Conclusions}

1. The considerable differences between the minimal and maximal chlorophyll values of individual plants in both years and nurseries showed a possibility for the selection of individual plants possessing high chlorophyll concentration in combinations with other desirable traits.

2. The maximal chlorophyll values were observed during anthesis. However, the individual plant selection by this trait should be done at the heading stage to avoid the cross pollination among the plants possessing desirable traits and discarded plants.

\section{Acknowledgements}

This work was supported by the Research Council of Lithuania under Grant, No. MIP-073/2012.

Received 20102014

Accepted 15042015

\section{References}

Arunyanark A., Jogloy S., Varasoot N., Akkasaeng C., Kesmala T., Patanothai A. 2009. Stability of relationship between chlorophyll density and soil plant analysis development chlorophyll meter readings in peanut across different drought stress conditions. Asian Journal of Plant Science, 8: 102-110 http://dx.doi.org/10.3923/ajps.2009.102.110

Babar M. A., Reynolds M. P., van Ginkel M., Klatt A. R., Ran W., Stone M. L. 2006. Spectral reflectance to estimate genetic variation for in-season biomass, leaf chlorophyll, and canopy temperature in wheat. Crop Science, 46: 1046-1057

http://dx.doi.org/10.2135/cropsci2005.0211 
Barney J. N., Mann J. J., Kyser G. B., Blumwald E., van Deynze A., DiTomaso J. M. 2009. Tolerance of switch grass to extreme soil moisture stress: ecological implications. Plant Science, 177: 724-732 http://dx.doi.org/10.1016/j.plantsci.2009.09.003

Butkutė B., Lemežienė N., Cecevičienè J., Liatukas Ž., Dabkevičienè G. 2013. Carbohydrate and lignin partitioning in switchgrass (Panicum virgatum L.) biomass as a bioenergy feedstock. Zemdirbyste-Agriculture, 100 (3): $251-260$ http://dx.doi.org/10.13080/z-a.2013.100.032

Chunjiang Z., Aning J., Wenjiang H., Keli L., Liangyun L., Jihua W. 2007. Evaluation of variable-rate nitrogen recommendation of winter wheat based on SPAD chlorophyll meter measurement. New Zealand Journal of Agriculture Research, 50: 735-741 http://dx.doi.org/10.1080/00288230709510345

Costa C., Frigon D., Dutilleul P., Dwyer L. M., Pillar V. D., Steward D. W., Smith D. L. 2003. Sample size determination for chlorophyll meter reading on maize hybrids with a broad range of canopy type. Journal of Plant Nutrition, 26: $1117-1130$ http://dx.doi.org/10.1081/PLN-120020079

Demirbas A. 2003. Relationships between heating value and lignin, fixed carbon, and volatile material contents of shells from biomass products. Energy Sources, 25: 629-635 http://dx.doi.org/10.1080/00908310390212336

Elbersen I. H. W. 2001. Final Report FAIR 5-CT97-3701 Switchgrass. Switchgrass (Panicum virgatum L.) as an alternative energy crop in Europe initiation of a productivity network. Wageningen, The Netherlands, $90 \mathrm{p}$.

Fike J. H., Parrish D. J., Wolf D. D., Balasko J. A., Green J. J., Rasnake M., Reynolds J. H. 2006. Switch grass production for the upper Southeastern USA: influence of cultivar and cutting frequency on biomass yields. Biomass and Bioenergy, 30: 207-213 http://dx.doi.org/10.1016/j.biombioe.2005.10.008

Giunta F., Motzo R., Deidda M. 2002. SPAD readings and associated leaf traits in durum wheat, barley and triticale cultivars. Euphytica, 125: 197-205 http://dx.doi.org/10.1023/A:1015878719389

Hassan M. S., Khair A., Haque M. M., Azad A. K., Hamid A. 2009. Genotypic variation in traditional rice varieties for chlorophyll content, SPAD value and nitrogen use efficiency. Bangladesh Journal of Agricultural Research, 34: 505-515 http://dx.doi.org/10.3329/bjar.v34i3.3977

Kashiwagi J., Upadhyaya H. D., Krishnamurthy L. 2010. Significance and genetic diversity of SPAD chlorophyll meter readings (SCMR) in the chickpea (Cicer arietinum L.) germplasm in the semi-arid environments. Journal of Food Legumes, 23: 99-105

Kwrr C., Stewart C. N. 2012. Gene flow matters in switchgrass (Panicum virgatum L.), a potential widespread biofuel feedstock. Ecology Applied, 22: 3-7 http://dx.doi.org/10.1890/11-1516.1

Madakadze I. C., Stewart K.., Madakadze R. M., Peterson P. R., Coulman B. E., Smith D. L. 1999. Field evaluation of the chlorophyllmeter to predict yield and nitrogen concentration of switchgrass. Journal of Plant Nutrition, 22: 1001-1010 http://dx.doi.org/10.1080/01904169909365689

Martinez D. E., Guiamet J. J. 2004. Distortion of the SPAD 502 chlorophyll meter reading by changes in irradiance and leaf water status. Agronomy for Sustainable Development, 24: $41-46$
McLaughlin S. B., Kszos L. A. 2005. Development of switchgrass (Panicum virgatum) as a bioenergy feedstock in the United States. Biomass and Bioenergy, 28: 515-535 http://dx.doi.org/10.1016/j.biombioe.2004.05.006

Mitchell J. L. B. 2012. Cool temperature effects on productivity and photosynthesis of two biomass fuel species: switchgrass (Panicum virgatum) and miscanthus (Miscanthus $\times$ giganteus): MS thesis. Virginia Techworks, Blacksburg, USA

Monti A. 2012. Switchgrass: a valuable biomass crop for energy. Green energy and technology, vol. IX. London, UK, 218 p. http://dx.doi.org/10.1007/978-1-4471-2903-5

Özyiğit Y., Bilgen M. 2011. Determination of nitrogen levels based on spectral reflectance values in sheep fescue (Festuca ovina L.). Turkish Journal of Field Crop, 16: 29-32

Ramesh K., Chandrasekaran B., Balasubramanian T. N., Bangarusamy U., Sivasamy R., Sankaran N. 2002. Chlorophyll dynamics in rice (Oryza sativa) before and after flowering based on SPAD (chlorophyll) meter monitoring and its relationship with grain yield. Journal of Agronomy, 188: 102-105 http://dx.doi.org/10.1046/j.1439-037X.2002.00532.x

Songsri P., Jogloy S., Holbrook C. C., Kesmala T., Varasoot N., Akkaseng C., Patanothai A. 2009. Association of root, specific leaf area and SPAD chlorophyll meter reading to water use efficiency of peanut under different available soil water. Agricultural Water Management, 96: 790-798 http://dx.doi.org/10.1016/j.agwat.2008.10.009

Udding J., Gelang-Alfredsson J., Piikki K., Pleijel H. 2007. Evaluation the relationship between leaf chlorophyll concentration and SPAD-502 chlorophyll meter readings. Photosynthesis Research, 91: 37-46 http://dx.doi.org/10.1007/s11120-006-9077-5

UPOV. 2002. International union for the protection of new varieties of plants. General introduction to the examination of distinctness, uniformity and stability and the development of harmonized descriptions of new varieties of plants. Geneva, Switzerland, $26 \mathrm{p}$.

Vogel K. P., Jung H. J. 2000. Genetic improvement of switchgrass and other herbaceous plants for use as biomass fuel feedstock. Critical Revue in Plant Science, 20: 15-45 http://dx.doi.org/10.1080/20013591099173

Wullschleger S. D., Sanderson M. A., McLaughlin S. B., Biradar D. P., Rayburn A. L. 1996. Photosynthetic rates and ploidy levels among populations of switchgrass. Crop Science, 36: 306-312 http://dx.doi.org/10.2135/cropsci19 96.0011183X003600020016x

Wullschleger S. D., Davis E. B., Borsuk M. E., Gunderson C. A., Lynd L. R. 2010. Biomass production in switchgrass across the United States: database description and determinants of yield. Agronomy Journal, 102: 1158-1168 http://dx.doi.org/10.2134/agronj2010.0087 
ISSN 1392-3196 / e-ISSN 2335-8947

Zemdirbyste-Agriculture, vol. 102, No. 2 (2015), p. 159-166

DOI 10.13080/z-a.2015.102.021

\title{
Chlorofilo verčių panaudojimas rykštėtosios soros (Panicum virgatum $\mathrm{L}$.) populiacijų genetinei variacijai ịvertinti vèsaus vidutinio klimato sąlygomis
}

\author{
Ž. Liatukas, N. Lemežienė, B. Butkutè, J. Cesevičienè, G. Dabkevičienė
}

Lietuvos agrarinių ir miškų mokslo centro Žemdirbystès institutas

\begin{abstract}
Santrauka
Tyrimo tikslas - ivvertinti rykštėtosios soros (Panicum virgatum L.) populiacijų SPAD chlorofilo matuoklio verčių skirtumus, siekiant pagerinti biokurui tinkamiausių augalų atranką. Chlorofilo kiekis matuotas penkis kartus augalų vegetacijos metu nuo stiebo ilgejjimo iki sèklų pildymosi tarpsnio. Chlorofilo kiekis didèjo nuo stiebo ilgèjimo iki žydejjimo, vèliau fiksuotas chlorofilo kiekio mažèjimas. Chlorofilo vertės žydejjimo metu pasiekè maksimalius vidutinius dydžius - 36,8-42,3 prietaiso verčių; verčių variacija priklausė nuo vertinimo metų ir vertinto augyno. Tai rodo, kad Lietuvos klimato sąlygos yra palankios rykštètosios soros fotosintezès veiklai. Pagal chlorofilo vertes populiacijų ir augalų tarpusavio skirtumai buvo žymūs. Atsižvelgiant ị tai, kad rykštetoji sora yra kryžmadulkis augalas, individai, pasižymintys didelèmis chlorofilo vertemis, turètų būti atrinkti iki žydejjimo. Šiuo tarpsniu skirtumai tarp populiacijų chlorofilo reikšmių variacijos koeficientų buvo panašūs i žydejjimo metu gautus tyrimo rezultatus. Vidutiniai populiacijų chlorofilo reikšmių variacijos koeficientai plaukèjimo metu svyravo nuo 4,98 iki $15,0 \%$. Toks variacijos lygis rodo mažus skirtumus populiacijų viduje, tačiau didesnę galimybę atrinkti augalus su pageidaujamomis chlorofilo reikšmėmis iš didesnio populiacijų skaičiaus. Augalų, pasižyminčių panašiomis chlorofilo vertėmis, atranka turètų pagreitinti naujų veislių kūrimą.
\end{abstract}

Reikšminiai žodžiai: atranka, augimo tarpsniai, chlorofilas, SPAD matavimai. 